\title{
Recent Advances in Horticultural Research
}

\section{East Malling Research Station}

1 HE annual report of the East Malling Research Station, Kent, for 1935, was published a short time ago (4s., including postage, from the Station). Administrative details are set forth in a supplementary report, leaving the main volume for the presentation of research findings.

The third section is the largest in the volume, and portrays the results of research work in progress. J. Amos, T. N. Hoblyn, R. J. Garner and A. W. Witt describe their studies in incompatibility between stock and scion, and Misses A. B. Breakbane and M. E. Renwick have also contributed to a solution of this problem by issuing a preliminary report upon the internal structure of root wood of stock and scion varieties. H. M. Tydeman reports further investigations in the root systems of apple trees, W. S. Rogers has considered the effects of soil moisture upon plant growth, using an ingenious vacuum moisture meter, and M. C. Vyvyan has a note on the moisture content of the stems of different rootstocks. Spring frosts at East Malling, from 1915 until 1935, are described by T. N. Hoblyn, whilst H. C. Chapelow and H. M. Tydeman deal with more general weather conditions.

Injection as a method of supplying deficiency of particular nutrients has been studied by W. A. Roach, who describes leaf injection, and by $J$. Hearman, B. F. Goodman Levy and W. A. Roach, who write on stem injection. Dr. H. Wormald has papers upon silver-leaf disease, Verticillium-wilt of hops, and a slime fungus on strawberry leaves, in addition to a general report on plant diseases. F. $H$. Beard, Dr. H. Wormald and W. A. Roach have investigated the bacterial canker of plum trees in relation to nutrition. Entomological investigations are concerned with the mites of hops and fruit trees, and the transmission of strawberry 'yellow-edge' virus, by Dr. A. M. Massee, and "Studies of Impregnation of Tree-banding Materials, by Dr. A. M. Massee and R. M. Greenslade. W. Steer has some "Observations on the Codlin Moth", whilst M. H. Moore, H. B. S. Montgomery and Dr. H. Shaw report upon field trials of several new fungicides and combined washes.

Section 4 of the Report is devoted to bulletins of interest to fruit growers. Here the progressive grower is advised upon "The Rapid Conversion of Unprofitable Fruit Trees by Grafting" (R. J. Garner), "Some Observations on the Roots of Fruit Trees" (W. S. Rogers), and "Some Notes on One Year's Experience with a Gas Store", by A. C. Painter. There are also articles on frost damage by W. A. Bane, the use of derris-root insecticide (W. Steer), upon walnut culture, by Miss J. B. Hamond, and on growing healthy raspberries, by $R$. V. Harris.

\section{Long Ashton Research Station}

The staff of the Agricultural and Horticultural Research Station at Long Ashton, Bristol, is to be congratulated upon the extensive results of research work portrayed in the Station's Annual Report for 1935. A rather severe financial loss was sustained when the incipient crop of fruit was ruined by frost in May of last year, but this does not seem to have curtailed the volume of investigation. G. T. Spinks and Dr. T. Swarbrick have made a virtue of necessity, and have described the frost and its effects in great detail. Dr. Swarbrick has also a progress report of investigations into the varieties of rootstocks for plum propagation.

Reports of work on plant pathology occupy the greater part of the volume. Descriptions of new or specific diseases and pests including a malady of strawberry resembling the American 'crimp' (L. Ogilvie and C. R. Thompson), new virus diseases of the tomato, and Sclerotinia-wilt of the hop, by L. Ogilvie, and Melasoma Populi, a chrysomelid pest of the basket willow, by Dr. H. G. H. Kearns. The incidence of reversion in seedling black currants and in clones derived from them is described by $E$. Umpleby and T. Swarbrick. New work has been done upon control of the woolly aphid (H. G. H. Kears and E. Umpleby), of flea beetles (Dr. C. L. Walton), and upon the effects of calcium cyanamide on pea and potato sickness by C. L. Walton, L. Ogilvie and P. W. Brian. Drs. H. G. H. Kearns and H. Martin have investigated the action of lauryl rhodanate as an egg-killing wash, and they have had the co-operation of R. W. Marsh in an investigation of combined washes, designed to eradicate a number of pests or diseases.

A number of papers on eider and fruit products include "Low-temperature Keeving of Cider", by V. L. S. Charley, "Experiments on the Improvement of the Juice from Culinary and Dessert Apples by Maceration with Pressed Bittersweet Pomace", by P. T. P. Pickford, and "Investigations on Fruit Products" by V. L. S. Charley. The last-mentioned paper includes several useful descriptions of modern methods of making fruit syrups, squashes and wines.

The investigations on willow culture are represented by a paper by H. P. Hutchinson, discussing the planting of the cricket bat willow on sewage farms, and a very gratifying report from the Berkeley Square Advisory Centre is also included in the volume. This organization has answered more than 6,500 inquiries, as against 4,813 in 1934 , and this in spite of an increased amount of advisory work handled directly by the Long Ashton Research Station.

\section{Cheshunt Research Station}

The twenty-first Annual Report, for 1935, of the Cheshunt Experimental and Research Station, Turner's Hill, Cheshunt, Herts, sets forth the results of a very considerable volume of original investiga. tion. The director, Dr. W. F. Bewley, reviews the whole work of the organization, and also discusses the practical value of experiment and trial work in progress under his ægis. This includes such useful features as the use of straw to provide a more efficient distribution of heat in soil sterilization, the employ. ment of peat as a surface rooting medium for tomatoes, and the provision of soil heat. Mr. P. H. Williams has a very interesting paper on the overwintering of a perennial Phragmidium rust of the rose. Dr. H. L. White describes the 'damping-off' disease of lettuce, the crown-rot of rhubarb, the stem-rots and Verticillium wilt of the carnation. A disease of cultivated 
heaths has been studied by Miss E. Oyler and Dr. Bewley, who find that it is caused by the fungus Phytophthora Cinnamomi. New work on virus diseases by Dr. G. C. Ainsworth includes the description of 'bushy-stunt' of tomato, a disease of the 'fern-leaf' type upon the same host, fig mosaic, and a virus disease of water-cress. Mr. E. R. Speyer has turned the entomological investigations to a study of various injuries caused by thrips, particularly on carnations and roses. The uses of the new spray fluids, copper oxychloride, copper salicylanilide, and cuprous cyanide, are discussed by Mr. W. H. Read, whilst Dr. O. Owen has investigated the use of chlorate weed killers, and other problems. In the realm of physiology, Messrs. B. D. Bolas and I. W. Selman have studied the movement of assimilate in seedling tomato plants, and Mr. D. W. Goodall considers some of the causes of variation in growth-rate of the tomato. Finally, a modest report from the Station's Extension Officer, Mr. O. B. Orchard, shows that the important work of translating research findings into practical technique receives the energetic attention it deserves.

The work of the Station is made possible by the Nursery and Market Garden Industries' Development Society, Ltd., and it is encouraging to note that an endowment fund has now been opened. The Society's late president, H. O. Larsen, has performed his last act of generosity to the Station by a bequest of $£ 2,000$.

\section{British Thunderstorms}

$\mathrm{I}^{\mathrm{T}}$ $\mathrm{T}$ is a fortunate circumstance for British climatology that there has never been a lack of scientifically. minded laymen ready and willing to co-operate in large-scale observational work. The late G. J. Symons and his successor, Dr. H. R. Mill, found it possible to enrol more than five thousand voluntary observers of rainfall. Quite recently, as we learn from the annual report of the Director of the Meteorological Office, more than eight hundred observers responded to an invitation to co-operate in a special investigation of mist and fog.

Mr. S. Morris Bower began his work on summer thunderstorms in 1931, when he invited co-operation in a project to record storms occurring between the months of April and September. Prior to that date, he had been engaged on a census of winter thunder. storms, following earlier work on similar lines by Capt. C. J. P. Cave. Nearly a thousand observers assisted Mr. Morris Bower in 1931; in 1934 the number of observers had risen to 1,254*. That is a very large number of persons to take part in a purely private enterprise, and it affords remarkable evidence of the extent to which scientific zeal is disseminated among the general population. We may conclude that the enthusiastic private investigator is assured of public support in a piece of work that seems worth doing, notwithstanding the official meteorological service, to the maintenance of which the observers themselves have to contribute as tax. payers.

That leads us to reflect upon the relationship which should exist between the official servicerepresented by the Meteorological Office-and a private organization such as that maintained by Mr. Morris Bower. So far as climatology is concerned, the function of the Meteorological Office is to collect and preserve for public use an adequate number of weather records from all parts of the British Isles. In pursuance of that aim, it maintains about fifty official stations ; the records from these are supplemented by about three hundred cooperating 'climatological' stations, most of which are maintained by local authorities. The principle of voluntary co-operation has, indeed, been a funda-

- Survey of Thunderstorms in the British Islands. British Thunderstorms, continuing Summer Thunderstorms. Fourth Annual Report 1934. By S. Morris Bower and Others. Vol. 2, Part 1. Pp. $48+$ viii +4 plates. (Huddersfleld: Thunderstorm Census Organisation, 1936.) mental feature of British climatological work since the earliest days of the Meteorological Office. The 350 official and voluntary stations suffice for the general purposes of climatology; but they do not suffice for an intensive study of the geographical distribution of a particular element such as rainfall, fog or thunderstorms. Thus we have to recognize the need for a closer network of stations when problems of this character arise, and the need is best met by an ad hoc organization. The role of the special organization is to amplify and extend the work of the official climatological organization, just as the three hundred co-operating climatological stations amplify and extend the work of the fifty official stations. There is clear evidence that $\mathrm{Mr}$. Morris Bower and his collaborators have fully appreciated this aspect of their work. It is of interest to note that all the observers who participated in the special investigation of fog referred to above, and a large proportion of Mr. Morris Bower's thunderstorm observers, are drawn from the ranks of the five thousand or so rainfall observers of the British Rainfall Organization, which thus forms as it were a 'reservist' body of meteorological workers who may confidently be relied upon to furnish volunteers for any special piece of work.

To return to the report under notice-it is a wellproduced account of the summer thunderstorms of 1933 and 1934, illustrated with numerous charts (many in two colours), photographs and diagrams. In addition to the charts and statistics relating purely to the incidence of thunderstorms, there are sections on damage to house property, trees struck by lightning (by Mr. S. T. E. Dark) and on damage to wireless instaliations (by Mr. Ralph A. Price). The present writer feels that the report is rather lacking in details of individual storms. In "British Rainfall" one finds a good deal of information about the rainfall occurring in noteworthy thunderstorms, and one would like to be able to turn to Mr. Morris Bower's report in order to find the corresponding information about the incidence of thunder and lightning. Such information exists in the form of manuscript records, and it is to be hoped that it will find its way into the report as funds allow. Meanwhile, Mr. Morris Bower and his collaborators are, nevertheless, to be congratulated on the results of their ambitious undertaking. E. G. Bilham. 